\title{
PELAKSANAAN PERLINDUNGAN HUKUM TERHADAP TANGGUNG JAWAB DOKTER JAGA DI INSTALASI GAWAT DARURAT BERDASARKAN HUKUM POSITIF INDONESIA \\ Oleh: RUDIANTO ${ }^{64}$
}

\begin{abstract}
Service at IGD many find difficult, such as the State of the patient is not conscious and there is no family that takes, so the doctor IGD should get legal protection in the conduct of medical action. The problem occurs because the doctor IGD in conditions like this should serve patients in the shortest - in short with the doctor in the service of the response time of the IGD is less than 5 (five) minutes, in order to save lives and more disability prevention further, while the doctor IGD that is in the RS are currently limited in number.

The purpose of research to analyse the implementation of the responsibility of the doctor in dealing with patients at IGD hospital. This type of research is descriptive, the juridical sociological approach is the method. The primary data source as the primary data collected from the field, and secondary data as supporting data. The data obtained were analyzed using qualitative methods, with the constant comparison analysis models and techniques of analysis done with the method of Theoretical Interpretation.

Aspects of the implementation of the responsibility of the doctor IGD-positive, however there are doctor IGD substitute that does not have SIP for lack of doctor IGD especially when holiday Lebaran. Doctor who practise without having a SIP don't get legal protection, from the beginning of the Administration had broken the law and may be subject to disciplinary action from the City/County Health Department in addition to criminal sanctions as set forth in Article 76 of ACT No. 29 of the year 2004 about the practice of medicine.

Keywords: legal protection, doctor, patient
\end{abstract}

\section{ABSTRAK}

Pelayanan di IGD banyak menjumpai keadaan sulit, seperti pasien tidak sadar dan tidak ada keluarga yang mengantar, sehingga dokter jaga IGD harus mendapat perlindungan hukum dalam melakukan tindakan medis. Permasalahan terjadi karena dokter jaga IGD dalam kondisi seperti ini harus melayani pasien dalam waktu yang sesingkat-singkatnya dengan waktu tanggap pelayanan dokter di IGD kurang dari 5(lima) menit, guna menyelamatkan nyawa dan pencegahan kecacatan lebih lanjut, sementara dokter jaga IGD yang ada di RS saat ini jumlahnya terbatas.

Tujuan penelitisan untuk menganalisis pelaksanaan tanggung jawab dokter jaga dalam menangani pasien di IGD Rumah Sakit. Tipe penelitian adalah bersifat deskriptif, metode pendekatan adalah yuridis sosiologis. Sumber data primer sebagai data utama yang diambil dari lapangan, dan data sekunder sebagai data pendukung. Data yang diperoleh dianalisis menggunakan metode kualitatif, dengan model analisis perbandingan konstan dan teknik analisis dilakukan dengan metode Theoritical Interpretation.

Aspek pelaksanaan tanggung jawab dokter jaga IGD yang positif, namun ada dokter jaga IGD pengganti yang tidak mempunyai SIP karena kekurangan dokter jaga IGD terutama saat hari libur Lebaran. Dokter jaga pengganti yang berpraktik tanpa memiliki SIP tidak mendapatkan perlindungan hukum, sejak semula telah melanggar hukum administrasi dan dapat dikenai sanksi disiplin dari Dinas Kesehatan Kota/Kabupaten selain sanksi pidana seperti diatur dalam Pasal 76 UU No. 29 tahun 2004 tentang Praktik Kedokteran.

Kata kunci: perlindungan hukum, dokter, pasien

${ }^{64}$ RSU Santa Elizabeth Purwokerto, HP. 085726069699 


\section{A. Pendahuluan}

Seorang dokter dalam
menjalankan tugasnya mempunyai
alasan yang mulia, yaitu berusaha
mempertahankan supaya tubuh pasien
tetap sehat atau berusaha untuk
menyehatkan tubuh pasien, atau
setidak-tidaknya berbuat untuk
mengurangi penderitaan pasien. Oleh
karenanya dengan alasan yang
demikian wajar apabila apa yang
dilakukan oleh dokter itu layak untuk
mendapatkan perlindungan hukum
sampai batas-batas tertentu. Sampai
batas mana perbuatan dokter itu dapat
dilindungi oleh hukum, inilah yang
menjadi permasalahan. Mengetahui
batas tindakan yang diperbolehkan
menurut hukum, merupakan hal yang
sangat penting, baik bagi dokter
maupun bagi pasien dan para aparat
penegak hukum. ${ }^{65}$ Instalansi Gawat Darurat (IGD)
merupakan salah satu unit di rumah
sakit yang memberikan pelayanan
kepada penderita gawat darurat dan
merupakan bagian dari rangkaian upaya
penanggulangan penderita gawat
darurat yang perlu diorganisir. Unit ini
dipimpin oleh seorang dokter jaga
dengan tenaga dokter ahli dan
berpengalaman dalam menangani

\footnotetext{
${ }^{65}$ Bahder Johan Nasution, 2005, Hukum Kesehatan Pertanggungjawaban Dokter, Jakarta: Rineka Cipta, hlm. 23
}

Pelayanan Gawat Darurat (PGD), yang kemudian bila dibutuhkan akan merujuk pasien kepada dokter spesialis tertentu. Pelayanan di IGD banyak menjumpai keadaan sulit, seperti pasien tidak sadar dan tidak ada keluarga yang mengantar, sehingga dokter jaga IGD harus mendapat perlindungan hukum dalam melakukan tindakan medis. Permasalahan terjadi karena dokter jaga IGD dalam kondisi seperti ini harus melayani pasien dalam waktu yang sesingkat-singkatnya dengan waktu tanggap pelayanan dokter di IGD kurang dari 5(lima) menit, guna menyelamatkan nyawa dan pencegahan kecacatan lebih lanjut, sementara dokter jaga IGD yang ada di RS saat ini jumlahnya terbatas.

Menurut Kamus Besar Bahasa Indonesia, dokter jaga diartikan sebagai dokter yang mendapat giliran bertugas atau berpraktik pada hari atau waktu tertentu (pada hari libur dan sebagainya). Istilah dokter jaga dapat dilihat pada Standar Prosedur Operasional Rumah Sakit, seperti di RSUD Tani dan Nelayan Kecamatan Tilamuta Kabupaten Boalemo Provinsi Gorontalo, yaitu yang dimaksud dengan dokter jaga on site adalah tenaga medis di Rumah Sakit yang bertugas di Unit Gawat Darurat sesuai dengan jadwal dokter jaga on site UGD. ${ }^{66}$ Legal

\footnotetext{
${ }^{66}$ Anonim, tersedia di web site http://repository.maranatha.edu/7966/3/
} 
standing dokter jaga juga dapat dijumpai pada Pasal 1 Peraturan Walikota Payakumbuh Nomor 10 Tahun 2010 tentang Tambahan Penghasilan Berdasarkan Beban Kerja Khusus Bagi Dokter jaga, Pengawas Perawat, Pegawai Dinas Malam, dan Operator Cito di Lingkungan RSUD Dr. Adnaan WD Payakumbuh, yang menyebutkan bahwa dokter jaga adalah dokter umum RSUD Dr. Adnaan WD Payakumbuh berstatus PNS maupun CPNS yang bertugas sebagai dokter jaga di Instalasi Gawat Darurat dan Instalasi Rawat Inap di luar jam kerja hari kerja dan di luar hari kerja. ${ }^{67}$

Instalasi Gawat Darurat Rumah Sakit harus memiliki semua sumber daya yang dibutuhkan. Salah satunya yang dibutuhkan adalah dokter jaga yang harus berjaga di IGD selama dua puluh empat jam dalam sehari dan tujuh hari dalam seminggu. Dokter jaga di IGD bekerja sesuai dengan shift yang ditugaskan. Umumnya, satu hari terbagi atas tiga shiftyaitu shift pagi mulai dari jam 07.00 WIB s.d jam 14.00 WIB, shift siang mulai dari jam 14.00 WIB s.d jam 21.00 WIB dan shift malam mulai dari jam 21.00 WIB s.d jam 07.00 WIB. Banyak rumah sakit dengan IGD yang

0430050 Chapter1.pdf, diunduh tanggal 22 Februari 2017

${ }^{67}$ Peraturan Walikota Payakumbuh, tersedia di website https://portal.mahkamahkonstitusi.go.id/ eLaw/mg58ufsc89hrsg/14215dfe39552f acdd2f6130163ebc9a3ebe90316.pdf, $\mathrm{hlm} .3$ memiliki tenaga dokter hanya satu dokter umum, yang di dalam jam kerjanya seringkali merangkap sebagai dokter jaga ruangan, dokter Intensif Care Unit dan juga melayani pasien false emergency, sehingga menimbulkan beban kerja dokter jaga IGD meningkat. ${ }^{68}$

Berdasarkan pada permasalahan yang disebutkan berupa besarnya beban kerja dokter jaga IGD, ketidaktahuan akan kewajiban dokter dan kelalaian dalam melakukan tugasnya, maka permasalahan pelaksanaan tanggung jawab dokter jaga tersebut urgen untuk diteliti, melalui penelitian yang berjudul "Pelaksanaan Perlindungan Hukum terhadap Tanggung Jawab Dokter Jaga di Instalasi Gawat Darurat Berdasarkan Hukum Positif Indonesia".

\section{B. Perumusan Permasalahan}

Berdasarkan uraian tersebut di atas dapat dirumuskan masalah dalam makalah ini adalah:

1. Bagaimana perlindungan hukum terhadap dokter jaga di IGD RS berdasarkan hukum positif Indonesia?

2. Bagaimana pelaksanaan tanggung jawab dokter jaga
${ }^{68}$ Anonim, Dasar Perhitungan Ketenagaan IGD RS, tersedia di web site http://dokumen.tips/embed/dasar- perhitungan-ketenagaan-rs.html, diunduh tanggal 1 Desember 2016 


\section{9 | Jurnal Idea Hukum}

Vol. 4 No. 2 Oktober 2018

Magister Hukum Fakultas Hukum Universitas Jenderal Soedirman

dalam menangani pasien di IGD Rumah Sakit?

\section{Metode Penelitian}

Metode pendekatan dalam penelitian ini adalah yuridis sosiologis dengan tipe penelitian adalah bersifat deskriptif. Penelitian ini dilaksanakan di beberapa rumah sakit di Purwokerto dengan sampel penelitian adalah para dokter jaga IGD di 3 (tiga) RSU tipe C di Purwokerto, yaitu: RSU St. Elisabeth, RSU Ananda, RST Wijaya Kusuma yang ditentukan dengan metode purposive sampling. Sumber data yang diperoleh dari data primer sebagai data utama yang diambil dari lapangan, dan data sekunder sebagai data pendukung, meliputi bahan hukum primer yaitu hukum positif Indonesia yang pengatur perlindungan hukum dokter, yaitu:Undang-Undang Nomor 36 Tahun 2009 tentang Kesehatan, UndangUndang Nomor 44 Tahun 2009 tentang Rumah Sakit, dan Undang-Undang Nomor 29 Tahun 2004 tentang Praktik Kedokteran; bahan hukum sekunderberupa buku-buku, karya ilmiah, hasil penelitian, jurnal, makalah atau artikel baik di internet maupun media massa dan bahan hukum tersier yaitu Kamus Besar Bahasa Indonesia.

$$
\text { Metode pengumpulan data }
$$
disesuaikan dengan sumber data yang ditentukan yaitu terhadap data primer menggunakan kuesioner dan pengamatan; terhadap data sekunder dilakukan dengan studi kepustakan (library research) atau dokumen dari peraturan perundang-undangan yang ada, hasil penelitian sebelumnya, artikel baik dari media massa maupun internet. Hasil penelitian disajikan dalam bentuk uraian yang bersifat deskriptif sistematik. Data yang diperoleh dianalisis menggunakan metode kualitatif, dengan model Constan Comparative Analisis (analisis perbandingan konstan dan teknik analisis dilakukan dengan metode Theoritical Interpretation.

\section{Pembahasan}

1. Perlindungan Hukum terhadap Dokter Jaga di IGD RS Berdasarkan Hukum Positif Indonesia

Undang-Undang No. 29 tahun 2004 tentang Praktik Kedokteran, UU No. 36 tahun 2009 tentang Kesehatan dan UU No. 44 tahun 2009 tentang Rumah Sakit serta UU No. 36 tahun 2014 tentang Tenaga Kesehatan merupakan peraturan perundang-undangan yang memberikan perlindungan dan kepastian hukum (rechtszekerheid) bagi dokter dalam menjalankan praktik kedokteran, termasuk terhadap dokter jaga IGD di RS dalam pertolongan gawat darurat untuk penyelamatan nyawa dan 
pencegahan kecacatan. Dokter mendapatkan pembenaran yang diberikan oleh hukum dalam melakukan tindakan medis terhadap pasien dalam upaya memelihara dan meningkatkan derajat kesehatan. Tindakan medis terhadap tubuh manusia yang dilakukan oleh bukan dokter dapat digolongkan sebagai tindak pidana. Berbagai upaya hukum yang dilakukan dalam memberikan perlindungan hukum kepada dokter sebagai pemberi pelayanan kesehatan telah banyak dilakukan, akan tetapi kemajuan ilmu pengetahuan dan teknologi kedokteran yang berkembang sangat cepat tidak seimbang dengan perkembangan hukum. Perangkat hukum yang mengatur penyelenggaraan praktik kedokteran dirasakan belum memadai, selama ini masih didominasi oleh kebutuhan formal dan kepentingan pemerintah, sedangkan porsi profesi masih sangat kurang.

Perlindungan hukum yang diberikan oleh hukum positif Indonesia, yang dikehendaki oleh dokter jaga IGD RS ialah yang dapat memberikan kepastian hukum dan keadilan terhadap profesi kedokteran. Kepastian diartikan sebagai kejelasan norma sehingga dapat dijadikan pedoman bagi masyarakat yang dikenakan peraturan ini. Pengertian kepastian tersebut dapat dimaknai bahwa ada kejelasan dan ketegasan terhadap berlakunya hukum di dalam masyarakat. Hukum bertugas menciptakan kepastian hukum karena bertujuan untuk menciptakan ketertiban dalam masyarakat. ${ }^{69}$

Pada umumnya keadilan merupakan penilaian yang hanya dilihat dari pihak yang menerima perlakuan saja: para yustisiabel (pada umumnya pihak yang dikalahkan dalam perkara perdata) menilai putusan hakim tidak adil. Jadi, penilaian tentang keadilan ini pada umumnya hanya ditinjau dari satu pihak saja, yaitu pihak yang menerima perlakuan. Keadilan kiranya tidak harus hanya dilihat dari satu pihak saja, tetapi harus dilihat dari dua

69 Tata Wijayanta, Asas Kepailitan Hukum, Keadilan dan Kemanfaatan dalam Kaitan dengan Putusan Kepailitan Pengadilan Niaga, tersedia di website http://www.akademik.fh.unsoed.ac.id, diunduh tanggal 16 Juli 2017 


\section{1 | Jurnal Idea Hukum}

Vol. 4 No. 2 Oktober 2018

Magister Hukum Fakultas Hukum Universitas Jenderal Soedirman

pihak. $^{70}$ Keadilan menuntut supaya tiap-tiap perkara harus

ditimbang sendiri, ius suum cuique tribuere. Perlu disadari bahwa untuk menciptakan keadilan hukum diperlukan peran aktif dari berbagai pihak mulai dari pembentukan produk hukum hingga penegakan produk hukum.

\section{Tanggung Jawab Dokter Jaga} dalam Menangani Pasien di IGD RS

Pelaksanaan Tanggung Jawab

Dokter Jaga di IGD RS

1) Jumlah Dokter Jaga IGD

Berdasarkan Pasal 43 ayat (1) Permenkes RI No. 56 tahun 2014 tentang klasifikasi dan Perizinan Rumah Sakit, menyatakan bahwa Sumber daya manusia RSU kelas C terdiri atas salah satunya tenaga medis. Pada ayat (2) disebutkan bahwa tenaga medis sebagaimana dimaksud pada ayat (1) paling sedikit terdiri atas: 9 (sembilan) dokter umum untuk pelayanan medik dasar. Jumlah dokter jaga IGD di RSU Tipe C di
Purwokerto

sudah

memenuhi persyaratan

yang diatur dalam perundang-undangan.

2) Rata-rata jumlah pasien IGD dalam 1(satu) shift

Dari penelitian didapatkan data rata-rata jumlah pasien IGD ketiga RSU tipe C di Purwokerto, sebagian besar $\leq 20$ pasien dalam 1 (satu) shift. Cara perhitungan ketenagaan dokter jaga IGD adalah berdasarkan rasio jumlah kasus di IGD dalam 24 jam yaitu 1:20 kasus dibagi dalam 3 (tiga) shift (1-11). ${ }^{71}$ Semakin banyak jumlah pasien IGD yang ditanggani oleh dokter jaga IGD dalam 1 (satu) shift (7 jam), maka beban kerja dokter jaga IGD akan semakin berat.

3) Beban Kerja Dokter Jaga IGD di RS

Dari hasil penelitian, responden para dokterdokter jaga IGD yang mengatakan bahwa beban kerja dokter jaga IGD adalah berat memberi

\footnotetext{
${ }^{71}$ Anonim, Dasar Perhitungan Ketenagaan IGD RS, tersedia di web site http://dokumen.tips/embed/dasarperhitungan-ketenagaan-rs.html, diunduh tanggal 1 Desember 2016
} 
alasan karena sebagai tanggung jawab; dokter jaga IGD untuk shift sore dan malam merangkap jaga ruangan dan ICU, hari libur shift pagi dokter jaga IGD masih merangkap jaga poli. Sedangkan para responden para dokterdokter jaga IGD yang menyatakan bahwa beban kerja dokter jaga IGD adalah sedang memberi alasan karena jumlah pasien masih sedikit; jenis kasus relatif ringan; pasien relatif bisa tertangani sesuai respon time.

4) Tanggung jawab dokter jaga IGD di RS

Dari data-data di atas dapat ketahui bahwa semua RSU tipe C di Purwokerto dalam 1 shift dokter jaga IGD merangkap di unit lain, ICU dan ruangan terutama pada shift siang dan malam serta di hari libur. Semakin banyak tanggung jawab dokter jaga IGD, yaitu merangkap tugas sebagai dokter jaga ICU dan ruangan, terutama pada shift sore dan malam serta di hari libur, maka akan semakin berat beban kerja dokter jaga IGD. Hal ini dapat menimbulkan masalah keterlambatan penanganan kepada pasien di IGD, yang berpotensi terjadinya tuntutan.

Tugas dari dokter jaga IGD, yaitu mengisi dan menandatangani: buku laporan pasien yang akan diperiksa oleh wakil kepala rumah sakit, formulir kejadian khusus yang akan diperiksa oleh kepala rumah sakit, surat visum;menyelenggarakan pelayanan kesehatan;memeriksa pasien ruangan bila ada konsultasi dari bagian ruangan; mengawasi dan mengarahkan perawat; melapor pada kepala atau wakil kepala rumah sakit bila ada kejadian penting atau khusus, ditambah dengan melaksanakan kewajiban sebagai dokter.Kewajiban dokter antara lain adalah melayani pasien dengan sukarela tanpa dipengaruhi oleh pertimbangan keuntungan pribadi, mendahulukan kepentingan pasien, dan menjaga kerahasiaan hal - 


\section{3 | Jurnal Idea Hukum}

Vol. 4 No. 2 Oktober 2018

Magister Hukum Fakultas Hukum Universitas Jenderal Soedirman

hal yang diketahui tentang pasien. $^{72}$

5) Kewenangan dokter jaga IGD di RS menurut peraturan internal RS

Menurut peraturan yang berlaku, seseorang yang telah lulus dan diwisuda sebagai dokter tidak secara otomatis boleh melakukan pekerjaan dokter. la harus lebih dahulu mengurus lisensi agar supaya memperoleh kewenangan untuk itu. Perlu dipahami bahwa tiaptiap jenis lisensi memerlukan basic science dan mempunyai batas kewenangan sendirisendiri. Tidak dibenarkan melakukan tindakan medik melampaui batas kewenangan yang telah ditentukan.

\section{Materiele}

wederrechtelijkheid dalam yurisprudensi Mahkamah Agung Indonesia telah diakui. Suatu tindakan medis seperti melakukan pembedahan didasarkan atas wewenang profesional dokter yang diakui

${ }^{72}$ Anonim, tersedia di web site http://repository.maranatha.edu/7966/3/ 0430050 Chapter1.pdf, hlm. 3, diunduh tanggal 22 Februari 2017 perundang-undangan yang mengatur mengenai hak dan wewenang dokter dalam menerapkan ilmu serta keterampilan profesinya (profesionele zorgvuldigheid), maka dapat dikatakan hak atau wewenang profesi tersebut merupakan dasar pembenaran yuridis yang meniadakan perbuatan melawan hukum yang merupakan pengecualian yang tidak tertulis (medisch exceptie). ${ }^{73}$

6) Sertifikat kompetensi yang dimiliki oleh dokter jaga IGD

$\begin{array}{lr}\text { Standar } & \text { Pelayanan } \\ \text { Minimal/SPM } & \text { untuk } \\ \text { pelayanan } & \text { Instalasi } \\ \text { Darurat } & \text { berdasarkan } \\ \text { Kepmenkes } & \end{array}$

No.129/Menkes/SK/II/2008 tentang Standar Pelayanan Minimal Rumah Sakit bahwa pemberi pelayanan gawat darurat yang bersertifikat yang masih berlaku

BLS/PPDG/GELS/ALS dengan standar $100 \%$.

\footnotetext{
${ }^{73}$ S. Soetrisno, 2010, Malpraktek Medik \& Mediasi Sebagai Alternatif Penyelesaian Sengketa, Tangerang: Telaga Ilmu Indonesia, hlm.22
} 
7) Kepemilikan STR dan SIP yang masih berlaku

Dokter berhak melakukan praktik dokter setelah memperoleh Surat Tanda Registrasi (STR) dan Surat Izin Praktik $(\mathrm{SIP}) .^{74}$ Seperti diatur dalam Pasal 2 Permenkes No.512/Menkes/Per/IV/200 7 tentang Izin Praktik dan Pelaksanaan Praktik Kedokteran, dan Pasal 29 Undang-Undang No. 29 tahun 2004 tentang Praktik Kedokteran. Dengan demikian dokter yang telah memperoleh STR tersebut memiliki wewenang melakukan praktik kedokteran dan kedokteran gigi sesuai dengan pendidikan dan kompetensi yang dimiliki (Pasal 35 UU No. 29 tahun 2004), setelah memperoleh SIP.

8) Pengganti dokter jaga IGD bila yang bertugas berhalangan

Untuk kepentingan pemenuhan kebutuhan pelayanan medis, surat tugas dapat diberikan oleh Kepala Dinas Kesehatan

74 M.Jusuf Hanafiah dan Amri Amir, 2016, Etika Kedokteran \& Hukum Kesehatan, Jakarta: Penerbit Buku Kedokteran EGC, hlm.73
Propinsi atas nama Menteri kepada dokter spesialis atau dokter gigi spesialis tertentu yang telah memiliki SIP untuk bekerja di sarana pelayanan kesehatan atau rumah sakit tertentu tanpa memerlukan SIP di tempat tersebut, berdasarkan permintaan Kepala Dinas Kesehatan Kab/Kota, seperti diatur dalam Pasal 15 ayat (1) PermenkesNo. 2052/Menkes/Per/X/2011 tentang Izin Praktik dan Pelaksanaan Praktik Kedokteran. Jadi surat tugas tidak bisa diberikan oleh Direktur RS kepada dokter jaga IGD pengganti, dokter pengganti harus memiliki SIP dan STR di RS tersebut.

9) Implementasi Informed consent terhadap pasien Gawat Darurat di IGD RS

Dari hasil penelitian diketahui bahwa implementasi informed consent terhadap pasien gawat darurat di IGD RSURSU tipe C di Purwokerto masih banyak yang belum mengetahui bahwa setiap tindakan kedokteran yang mengandung risiko tinggi harus memperoleh 


\section{5 | Jurnal Idea Hukum}

Vol. 4 No. 2 Oktober 2018

Magister Hukum Fakultas Hukum Universitas Jenderal Soedirman

persetujuan tertulis yang

ditandatangani oleh yang

berhak memberikan

persetujuan, seperti diatur

dalam Pasal 3 ayat (1)

Permenkes No. 290 tahun

2008 tentang Persetujuan

Tindakan Kedokteran.

Tindakan kedokteran yang tidak termasuk tindakan

berisiko tinggi dapat

diberikan dengan

persetujuan lisan, dapat

diberikan dalam bentuk

ucapan setuju atau bentuk

gerakan menganggukkan

kepala yang dapat diartikan

sebagai ucapan setuju,

namun bila persetujuan

secara lisan yang diberikan

oleh pasien dianggap

meragukan, maka dapat

dimintakan persetujuan

tertulis, sehingga jangan

sampai pelayanan di IGD

untuk pasien gawat darurat

mengalami keterlambatan

hanya karena menunggu

persetujuan dari

pasien/keluarga pasien

yang berwenang.

10) Pelaksanaan rekam medis

oleh dokter jaga di IGD

RSU-RSU tipe $C$ di

Purwokerto saat

menangani pasien gawat

darurat.
Menurut Pasal 5 ayat

(1) Permenkes No. 269 tahun 2008 tentang Rekam

Medis mengatur bahwa setiap dokter atau dokter gigi dalam menjalankan praktik kedokteran wajib membuat rekam medis. Rekam medis harus dibuat segera dan dilengkapi setelah pasien menerima pelayanan. Setiap pencatatan ke dalam rekam medis harus dibubuhi nama, waktu dan tanda tangan dokter, dokter gigi atau tenaga kesehatan tertentu yang memberikan pelayanan kesehatan secara langsung.

Dalam pedoman Pelayanan Gawat Darurat diatur bahwa catatan medis yang lengkap untuk setiap penderita:

Interpretasi:

(1) catatan medis minimum harus mencakup:

a) tanggal dan jam tiba

b) resume catatan klinik, laboratorium, $\quad \mathrm{x}$ ray

c) catatan tentang tindakan dan 


\author{
tanggal serta jam \\ dilakukan \\ d) nama dan tanda \\ tangan petugas \\ medis.
}

Dalam Permenkes No. 129 tahun 2008 tentang Standar Pelayanan Minimal Rumah sakit disebutkan bahwa indikator pelayanan rekam medis untuk kelengkapan pengisian rekam medis 24 jam setelah selesai pelayanan, dengan standar $100 \%$.

11) Sikap RS bila terjadi kasus tuntutan pasien terhadap dokter jaga IGD

Rumah sakit
bertanggung jawab atas
perbuatan melanggar
hukum yang dilakukan oleh
tenaga kesehatan yang
melaksanakan pelayanan
kesehatan dalam perjanjian
terapeutik. Demikian pula
dengan dokter yang dalam
menjalankan praktik
profesinya dibantu oleh
bawahan yang terdiri atas
perawat, bidan, asisten
dokter dan sebagainya.
Oleh karena itu, atas
kesalahan yang dilakukan
oleh bawahannya, rumah
sakit dan dokter dapat turut
mempertanggungjawabkan

kesalahan tersebut berdasarkan Pasal 1367 ayat $3 \mathrm{KUH}$ Perdata. $^{75}$ Pasal 46 UU No. 44 tahun 2009 tentang Rumah Sakit mengatur bahwa Rumah Sakit bertanggung jawab secara hukum terhadap semua kerugian yang ditimbulkan atas kelalaian yang dilakukan oleh tenaga kesehatan di Rumah Sakit. Hal itu juga diatur dalam Permenkes No. 69 tahun 2014 Kewajiban Rumah Sakit dan Kewajiban Pasien, Pasal 2 huruf $u$ yaitu setiap Rumah sakit mempunyai kewajiban melindungi dan memberikan bantuan hukum bagi semua petugas Rumah Sakit dalam melaksanakan tugas.

12) Standar Prosedur Operasional/SPO Pelayanan IGD di RS Menurut Pasal 44 ayat (1) UU No. 29 tahun 2004 tentang Praktik Kedokteran, bahwa dokter atau dokter gigi dalam menyelenggarakan praktik kedokteran wajib mengikuti

\footnotetext{
${ }_{75}^{75}$ Y.A Triana Ohoiwutun, 2008, Bunga Rampai Hukum Kedokteran, Malang: Bayumedia Publising, hlm. 68
} 


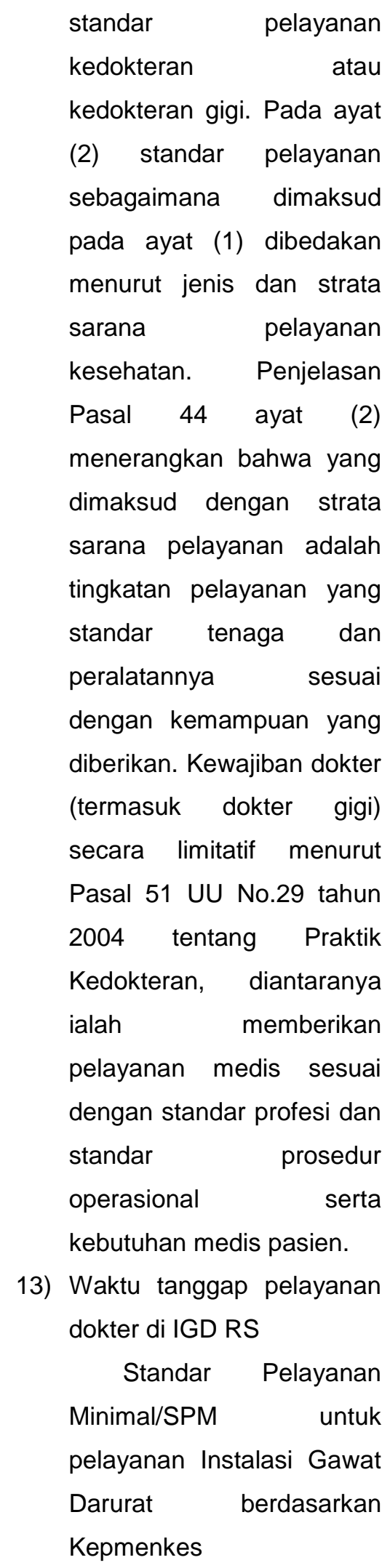

13) Waktu tanggap pelayanan dokter di IGD RS

No.129/Menkes/SK/II/2008 tentang Standar Pelayanan

Minimal Rumah Sakit, dan

diatur juga dalam Peraturan

Gubernur Jawa Tengah No.

27 tahun 2011 tentang

Penerapan dan Rencana

Pencapaian Standar

Pelayanan Minimal RSUD

\& RSJD Provinsi Jawa

Tengah, diantaranya ialah

waktu tanggap pelayanan

Dokter di Gawat Darurat

dengan standar $\leq 5$ (lima)

menit terlayani setelah

pasien datang.

Tanggung Jawab Dokter Jaga IGD menurut Hukum Positif Indonesia dapat dilihat dari aspek hukum administrasi, hukum perdata dan hukum pidana.

a. Tanggung Jawab Dokter menurut Hukum Administrasi

$$
\text { Aspek hukum }
$$

administrasi di sini dinilai dari sudut kewenangan, yaitu: apakah dokter yang bersangkutan berwenang atau tidak melakukan perawatan? Tenaga Kesehatan yang melakukan kesalahan dan atau kelalaian dalam melaksanakan profesinya dapat dikenakan tindakan disiplin. Tindakan disiplin yang dimaksud adalah salah satu bentuk 
tindakan administratif,
misalnya pencabutan izin
untuk jangka waktu tertentu
atau hukuman lain sesuai
dengan kesalahan yang
dilakukannya.

Menurut peraturan yang berlaku, seseorang yang telah lulus dan diwisuda sebagai dokter tidak secara otomatis boleh melakukan pekerjaan dokter. Dokter harus lebih dahulu mengurus lisensi agar supaya memperoleh kewenangan untuk itu. Perlu dipahami bahwa tiap-tiap jenis lisensi memerlukan basic science dan mempunyai batas kewenangan sendiri-sendiri. Tidak dibenarkan melakukan tindakan medik melampaui batas kewenangan yang telah ditentukan. Jika ketentuan tersebut dilanggar maka dokter dapat dianggap telah melakukan administratif malpraktik dan dapat dikenakan sanksi berupa pembekuan lisensi untuk sementara waktu.

Pasal 82 ayat (3) UU $\begin{array}{lr}\text { Tenaga } & \text { Kesehatan: } \\ \text { mengatur } & \text { bahwa } \\ \text { Pemerintah, pemerintah } & \text { daerah provinsi, dan } \\ \text { pemerintah } & \text { daerah }\end{array}$ kabupaten/kota sesuai dengan kewenangannya memberikan sanksi administrasi kepada Tenaga Kesehatan dan Fasilitas Pelayanan Kesehatan. Pasal 82 ayat (4): sanksi administrasi sebagaimana dimaksud pada ayat (3) dapat berupa:
a) Teguran lisan;
b) Peringatan tertulis
c) Denda administrasi; dan/atau
d) Pencabutan izin.

b. Tanggung Jawab Dokter menurut Hukum Perdata

Gugatan untuk meminta pertanggungjawaban dokter bersumber pada dua dasar hukum, yaitu: pertama, berdasarkan pada wanprestasi (contractual liability) sebagaimana diatur dalam Pasal 1239 KUHPerdata. Wanprestasi, diartikan bahwa dokter tidak memenuhi kewajibannya yang timbul dari adanya suatu perjanjian. Kedua, berdasarkan perbuatan melanggar hukum (onrechmatigedaad) sesuai dengan ketentuan Pasal 1367 KUHPerdata. $^{76}$

\footnotetext{
${ }^{76}$ Bahder Johan Nasution, 2005, Op.Cit., hlm. 63
} 


\section{9 | Jurnal Idea Hukum}

Vol. 4 No. 2 Oktober 2018

Magister Hukum Fakultas Hukum Universitas Jenderal Soedirman

Wanprestasi dalam
pelayanan kesehatan baru
terjadi bila telah terpenuhi
unsur-unsur berikut ini: ${ }^{77}$

a. Hubungan antara dokter dengan pasien terjadi berdasarkan kontrak terapeutik.

b. Dokter telah memberikan pelayanan kesehatan yang tidak patut yang menyalahi tujuan kontrak terapeutik.

c. Pasien menderita kerugian akibat tindakan dokter yang bersangkutan.

Hak pasien untuk mendapatkan ganti rugi atas suatu wanprestasi, di samping didasarkan pada ketentuan hukum perikatan juga didasarkan pada ketentuan hukum kesehatan sebagaimana diatur dalam Pasal 58 UU No. 36 tahun 2009 tentang Kesehatan. ${ }^{78}$

Dasar hukum yang kedua untuk melakukan gugatan adalah perbuatan melawan hukum. Untuk mengajukan gugatan

${ }^{77} \mathrm{Ibid}$

${ }^{78}$ Rinanto Suryadhimirtha, 2011, Hukum Malpraktik Kedokteran disertai Kasus dan Penyelesaiannya, Perpustakaan Nasional:KDT, hlm. 28 berdasarkan perbuatan

melawan hukum, harus

dipenuhi empat syarat sebagaimana diatur Pasal 1365 KUHPerdata. $^{79}$

1) Pasien harus mengalami suatu kerugian;

2) Ada kesalahan;

3) Ada hubungan kausal antara kesalahan dengan kerugian;

4) Perbuatan itu melawan hukum.

Ciri khas gugatan berdasarkan perbuatan melawan hukum dapat dilihat dari model pertanggunggungjawaban yang diterapkan yaitu: pertanggungjawaban karena kesalahan (fault liability) yang bertumpu pada tiga asas sebagaimana diatur oleh Pasal 1365, 1366, dan 1367 KUHPerdata. ${ }^{80}$

Suatu perbuatan dapat disebut sebagai kelalaian apabila memenuhi syarat sebagai berikut:

a) suatu tingkah laku yang menimbulkan kerugian, tidak sesuai dengan sikap hati-hati yang normal.

b) yang harus dibuktikan adalah bahwa tergugat
${ }^{79} \mathrm{lbid}$

${ }^{80} \mathrm{lbid}$ 
lalai dalam kewajiban berhati-hatinya terhadap penggugat.

c) kelakuan itu merupakan penyebab yang nyata dari kerugian yang timbul.

Gugatan yang didasarkan kepada perbuatan melawan hukum, harus dibuktikan dengan adanya hubungan kausal antara kesalahan dan kerugian yang diderita oleh pasien. Pemecahan problem kausalitas antara kesalahan dan kerugian dalam ilmu hukum dikenal dua ajaran pokok. ${ }^{81}$

a. Ajaran Conditio Sine Qua Non/ equivalentie theori oleh Von Buri:

Tiap

peristiwa/perbuatan

yang merupakan

syarat untuk timbulnya akibat merupakan sebab daripada akibat.

b. AjaranAdequate

verorzaking oleh Von

Kries:

Teori ini mengatakan bahwa yang dianggap

${ }^{81}$ Soerjono Soekanto, 1989, Soekanto. Soerjono, 1989, Aspek Hukum Kesehatan (Suatu Kumpulan Catatan), Jakarta: Penerbit Ind-Hill-Co, hlm. 145 sebagai sebab yang

menimbulkan akibat

adalah perbuatan yang

seimbang yang

menurut perhitungan

yang layak dapat

menimbulkan akibat

atau perbuatan itu

dapat dianggap

sebagai sebab

langsung dari akibat

(kerugian) yang

muncul.

c. Tanggung Jawab Dokter menurut Hukum Pidana

Pertanggungjawaban

pidana dalam istilah asing disebut dengan

teorekenbaardheid atau

criminal responsibility yang

menjurus kepada

pemidanaan pelaku dengan maksud untuk menentukan apakah seseorang terdakwa atau tersangka dapat dipertanggung jawabkan atas suatu tindakan pidana yang terjadi atau tidak.

Para ahli pidana mengemukakan untuk adanya pertanggungjawaban pidana harus dipenuhi tiga persyaratan, yaitu:

1) Harus ada perbuatan yang dapat dipidana, yang termasuk dalam 


\section{1 | Jurnal Idea Hukum}

Vol. 4 No. 2 Oktober 2018

Magister Hukum Fakultas Hukum Universitas Jenderal Soedirman

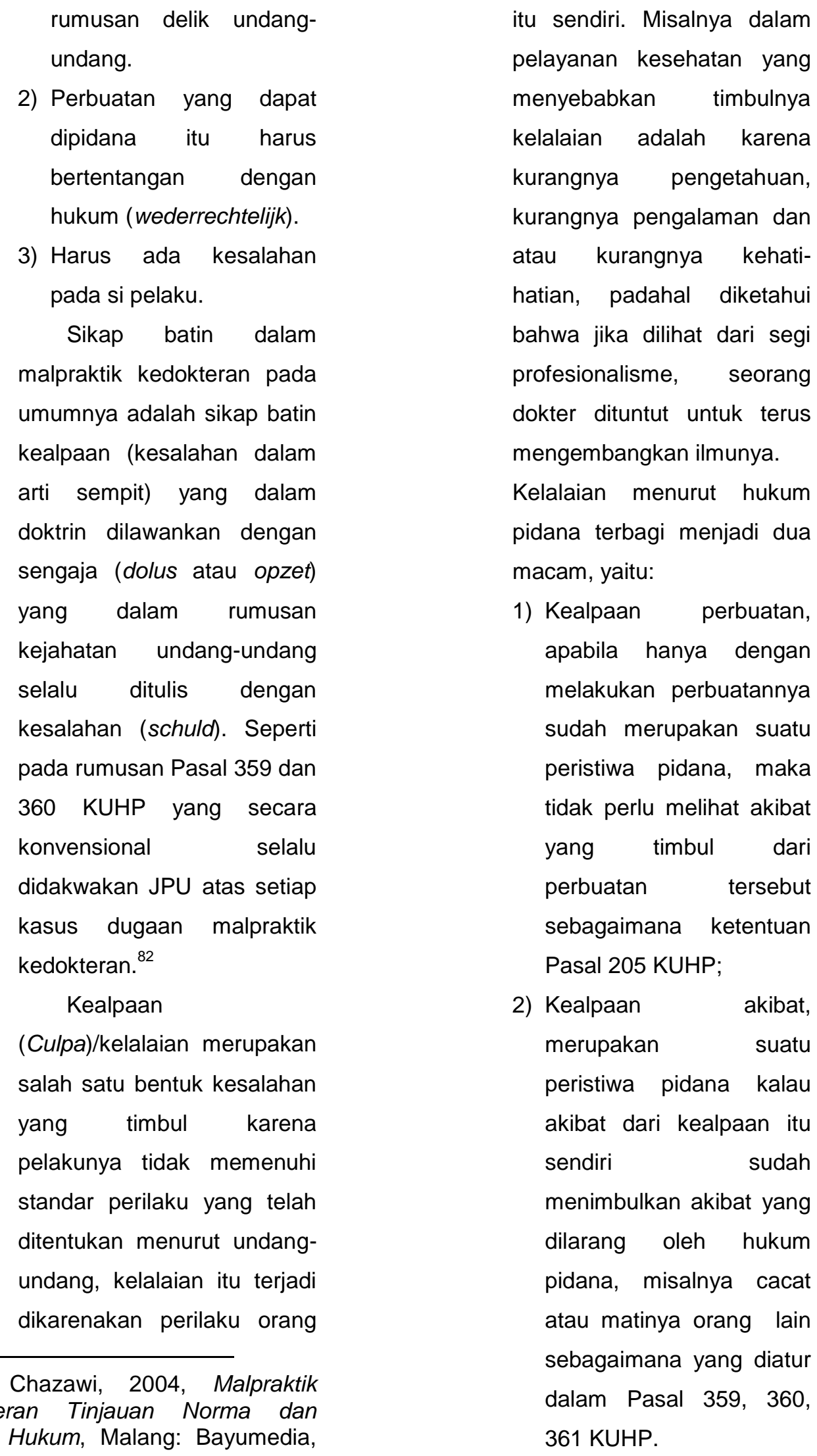

${ }^{82}$ Adami Chazawi, 2004, Malpraktik Kedokteran Tinjauan Norma dan Doktrin Hukum, Malang: Bayumedia, hlm. 84

itu sendiri. Misalnya dalam pelayanan kesehatan yang kurangnya pengetahuan, atau kurangnya kehatiatian, padahal diketahui dokter dituntut untuk terus mengembangkan ilmunya.

Kelalaian menurut hukum macam, yaitu:

1) Kealpaan perbuatan, apabila hanya dengan melakukan perbuatannya sudah merupakan suatu tidak perlu melihat akibat yang timbul dari perbuatan tersebut sebagaimana ketentuan Kealpaan akibat, merupakan suatu akibat dari kealpaan itu sendiri sudah menimbulkan akibat yang dilarang oleh hukum atau matinya orang lain sebagaimana yang diatur 361 KUHP. 
Tanggung Jawab Dokter menurut Hukum Pidana.

1. UU No. 36 tahun 2014 tentang

Tenaga

Kesehatan, Pasal 84:
(1) Setiap Tenaga
Kesehatan yang
melakukan kelalaian
berat yang
mengakibatkan

Penerima Pelayanan

Kesehatan luka berat

dipidana dengan

pidana penjara

paling lama 3 (tiga)

tahun.

(2) Jika kelalaian berat sebagaimana

dimaksud pada ayat

(1) mengakibatkan

kematian, setiap

Tenaga Kesehatan

dipidana dengan

pidana penjara

paling lama 5 (lima)

tahun.

Pasal 85 ayat (1)

mengatur tentang

ketentuan pidana bagi

setiap Tenaga Kesehatan

yang dengan sengaja

menjalankan praktik

tanpa memiliki STR, yaitu

dipidana dengan pidana

denda paling banyak

Rp. $100.000 .000,00$

(seratus juta). Pada ayat
(2) mengatur ketentuan pidana bagi setiap tenaga kesehatan warga negara asing yang dengan sengaja memberikan pelayanan kesehatan tanpa memiliki STR Sementara, dipidana dengan pidana denda paling banyak Rp. $100.000 .000,00$ (seratus juta rupiah).

Pasal 86 ayat (1) UU No. 36 tahun 2014 tentang Tenaga Kesehatan mengatur ketentuan pidana bagi setiap Tenaga Kesehatan yang menjalankan praktik tanpa memiliki, izin dipidanadengan pidana denda paling banyak Rp.100.000.000,00 (seratus juta rupiah). Ayat (2) mengatur tentang ketentuan pidana bagi setiap tenaga kesehatan warga negara asing yang dengan sengaja memberikan pelayanan kesehatan tanpa memiliki SIP, dipidana dengan pidana denda paling banyak

Rp. $100.000 .000,00$ (seratus juta rupiah). 


\section{3 | Jurnal Idea Hukum}

Vol. 4 No. 2 Oktober 2018

Magister Hukum Fakultas Hukum Universitas Jenderal Soedirman

2. UU No. 29 tahun 2004 tentang

Praktik

Kedokteran, meliputi

sebagai berikut:

Sanksi yang

dikenakan kepada dokter atau dokter gigi yang menjalankan praktik kedokteran tanpa memiliki STR dan SIP tercantum pada Pasal 75dan Pasal 76 UU No. 29 Tahun 2004 tentang Praktik Kedokteran.

Pasal 79 menyatakan bahwa setiap dokter atau dokter gigi yang praktik:

a) dengan sengaja tidak memasang papan nama sebagaimana dimaksud dalam Pasal 41 ayat (1);

b) dengan sengaja tidak membuat rekam medis sebagaimana dimaksud dalam Pasal 46 ayat (1); atau

c) dengan sengaja tidak memenuhi kewajiban sebagaimana dimaksud dalam Pasal 51 huruf a (tidak memberikan pelayanan medis sesuai dengan standar profesi dan standar prosedur operasional serta kebutuhan medis pasien), huruf $b$ (merujuk pasien ke dokter atau dokter gigi lain yang mempunyai keahlian atau kemampuan yang lebih baik, apabila tidak mampu melakukan suatu pemeriksaan atau pengobatan), huruf $\mathrm{c}$ (merahasiakan segala sesuatu yang diketahuinya tentang pasien, bahkan juga setelah pasien meninggal dunia), huruf $d$ (melakukan pertolongan darurat atas dasar perikemanusiaan, kecuali bila ia yakin ada orang lain yang bertugas dan mampu melakukannya), atau huruf e (menambah ilmu pengetahuan dan mengikuti perkembangan ilmu kedokteran atau kedokteran gigi).

Dipidana dengan pidana kurungan paling lama 1 (satu) tahun atau denda paling banyak $\mathrm{Rp}$. 
$50.000 .000,00 \quad$ (lima
puluh juta rupiah).
Berdasarkan
keputusan Mahkamah

Konstitusi No. 4/PUU-

V/2007

perihal

Pengujian UU No. 29

tahun 2004 tentang

Praktik Kedokteran

terhadap UUD Negara

RI tahun

1945,terhadap Pasal

75 ayat (1) dan Pasal

$76 \quad$ sepanjang

mengenai penjara

paling lama 3 (tiga)

tahun atau,Pasal 79

sepanjang mengenai

kurungan paling lama

1 (satu) tahun atau,

Pasal 79 huruf $c$

sepanjang mengenai

kata-kata atau huruf

etidak mempunyai

kekuatan mengikat.

Sifat putusan

Mahkamah Konstitusi

atau UU Praktik

Kedokteran bersifat

final dan mengikat,

maka terhadap

putusan tersebut tidak

terdapat upaya hukum

baik kasasi maupun

peninjauan kembali,

sehingga wajib

dihormati dan dilaksanakan dengan

rasa penuh tanggung

jawab oleh semua pihak. $^{83}$

3. UU No. 36 tahun 2009 tentang Kesehatan:

Pasal 190 ayat

(1) UU Kesehatan

mengatur tentang

ketentuan pidana, yaitu:

pimpinan fasilitas

pelayanan kesehatan

dan/atau tenaga

kesehatan yang

melakukan praktik atau

pekerjaan pada fasilitas

pelayanan kesehatan

yang dengan sengaja

tidak memberikan

pertolongan pertama

terhadap pasien yang

dalam keadaan gawat

darurat sebagaimana

dimaksud dalam Pasal 32

ayat (2) atau Pasal 85

ayat (2) dipidana dengan

pidana penjara paling

lama 2 (dua) tahun dan

denda paling banyak Rp.

${ }^{83}$ Biro Hukum dan Organisasi , 2007 ,

"Tinjauan Kasus Putusan Mahkamah Kostitusi (MK) dalam Pembentukan Sanksi Pidana pada Undang-Undang Praktik Kedokteran" disampaikan pada kegiatan Temu IImiah "Sistem Pemidanaan di Indonesia" dapat diunduh di https://bphn.go.id, diakses tanggal 25 Mei 2017 


$200.000 .000,00 \quad$ (dua
ratus juta rupiah).
Ayat (2): dalam hal
perbuatan sebagaimana
dimaksud pada ayat (1)
mengakibatkan terjadinya
kecacatan atau kematian,
pimpinan tasilitas
pelayanan kesehatan
dan/atau tenaga
kesehatan tersebut
dipidana dengan pidana
penjara paling lama 10
(sepuluh) tahun dan
denda paling banyak
Rp.1.000.000.000,00
(satu miliar rupiah).

Bila melihat peraturan perundang-undangan yang mengatur perlindungan hukum dokter jaga IGD berdasarkan hukum positif Indonesia, sudah cukup memberikan perlindungan hukum, hanya saja penerapannya belum ideal dan belum dapat diterapkan dengan sebaik-baiknya. Banyak faktorfaktor yang mempengaruhi bekerjanya hukum, menurut Robert B. Seidman menyatakan bahwa tindakan apapun yang akan diambil baik oleh pemegang peran, lembagalembaga pelaksana maupun pembuat undang-undang, selalu berada dalam lingkup kompleksitas kekuatan- kekuatan sosial, budaya, ekonomi, politik dan lain sebagainya. Dari faktor pembuat undang-undang, pemerintah telah membuat peraturan perundang-undangan, meliputi: UU No. 29 tahun 2004 tentang Praktik Kedokteran, UU No. 44 tahun 2009 tentang Rumah Sakit, UU No. 36 tahun 2009 tentang Kesehatan dan UU No. 36 tahun 2014 tentang Tenaga Kesehatan yang cukup dalam mengatur perlindungan hukum dan tanggung jawab dokter jaga IGD. Dari faktor pemegang peran, yaitu dokter jaga IGD yang menjalankan praktik profesinya. Masih dijumpai ada dokter yang tidak memiliki SIP di RS tempat dokter praktik di IGD, dengan alasan menjalankan praktik insidentil, menggantikan dokter yang berhalangan khususnya pada hari Libur Idul Fitri dimana sebagian besar dokter beragama Islam dan mudik lebaran, sehingga terjadi kekurangan dokter jaga. Dokter yang mengantikan telah mendapat surat tugas dari direktur RS yang bersangkutan, namun dokter tersebut telah melanggar hukum administratif berdasarkan Pasal 29 ayat (1) dan Pasal 36 UU No. 29 tahun 2004 tentang Praktik 
Kedokteran, sehingga dokter tersebut tidak mendapat perlindungan hukum. Rumah Sakit yang mempekerjakan dokter yang bersangkutan juga melanggar hukum administrasi berdasarkan Pasal 13 UU No. 44 tahun 2009 tentang Rumah Sakit.

Dari faktor penegakan hukum, belum ada pengawasan yang baik dari penegak hukum, Dinas Kesehatan terhadap dokter yang menjalankan praktik tanpa SIP/STR. Penelusuran dari aparat penegak hukum biasanya dilakukan setelah terjadi kejadian malpraktik yang merugikan pasien, bila ternyata dokter berpraktik tanpa SIP/STR dapat dikenakan pula sanksi administratif disamping pertanggungjawaban hukum perdata/pidana.

Seluruh kekuatan-kekuatan sosial ikut bekerja dalam setiap upaya untuk memfungsikan peraturan-peraturan yang berlaku, menerapkan sanksisanksinya, dan dalam seluruh akitivitas lembaga-lembaga pelaksananya. Terkait upaya mewujudkan sistem hukum yang efektif perlu penataan kembali kelembagaan hukum yang didukung oleh kualitas sumber daya manusia, kultur

$\begin{array}{lrr}\text { dan kesadaran } & \text { hukum } \\ \text { masyarakat yang } & \text { terus } \\ \text { meningkat, seiring } & \text { dengan } \\ \text { pembaharuan materi } & \text { hukum } \\ \text { yang terstruktur } & \text { secara } \\ \text { harmonis tanpa pertentangan } & \\ \text { dan tumpang tindih dan hukum } & \text { hecara terus menerus } \\ \text { diperbaharui sesuai } & \text { dengan } \\ \text { tuntutan } & \text { perkembangan } \\ \text { kebutuhan. } & \end{array}$

\section{G. Kesimpulan}

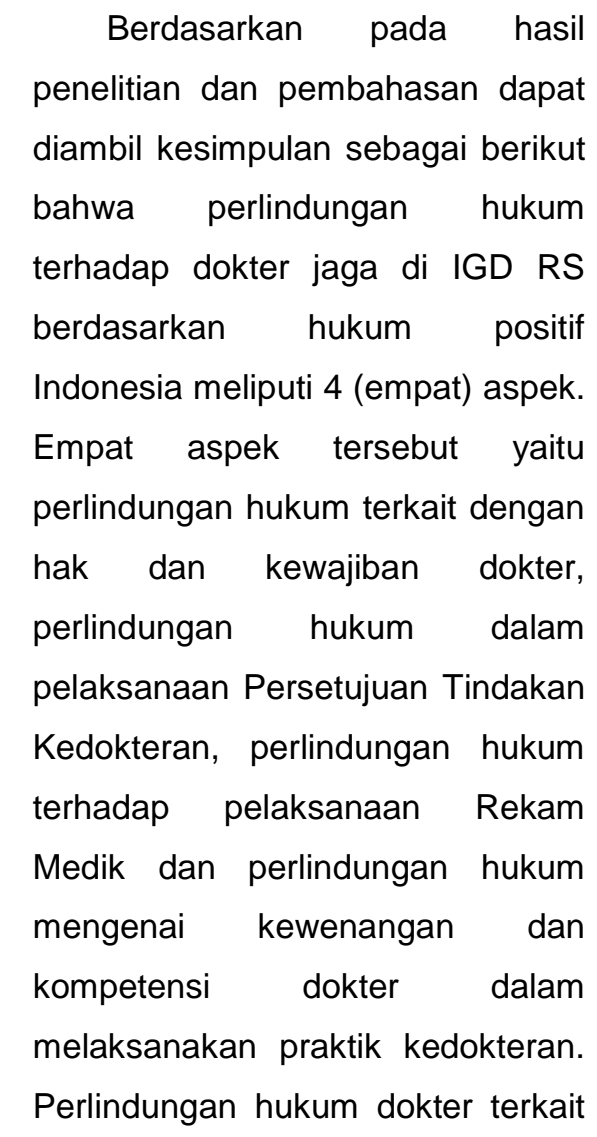

\footnotetext{
${ }^{84}$ Endang Sutrisno. Elya Kusuma Dewi, Dampak Putusan Mahkamah Agung Nomor 365 K/PID 2012 Terhadap Kinerja Dokter di Wilayah III Cirebon, tersedia di website http://journal.umy.ac.id, diunduh tanggal 16 Juli 2017
} 


\section{7 | Jurnal Idea Hukum}

Vol. 4 No. 2 Oktober 2018

Magister Hukum Fakultas Hukum Universitas Jenderal Soedirman

dengan 4 (empat) aspek tersebut di atas sudah diatur dalam UU No. 36 tahun 2014 tentang Tenaga Kesehatan, UU No. 36 tahun 2009 tentang Kesehatan, UU No. 44 tahun 2009 tentang Rumah Sakit dan UUNo. 29 tahun 2004 tentang Praktik Kedokteran.

Pelaksanaan tanggung jawab dokter jaga dalam menangani pasien di IGD RSU-RSU tipe C di Purwokerto, bahwa jumlah dokter jaga IGD tetap memenuhi persyaratan yang diatur dalam perundang-undangan; beban kerja dokter jaga IGD sedang; tanggung jawab dokter jaga IGD dalam satu shift jaga IGD merangkap di unit pelayanan lainnya; dokter jaga IGD diberi kewenangan menangani pasien emergensi dan false emergency, pasien ICU, pasien di bangsal perawatan serta melakukan konsultasi dengan dokter DPJP bila diperlukan; seluruh dokter jaga IGD memiliki SIP dan STR yang masih berlaku; sebagian besar dokter jaga IGD telah melakukan informed consentdan mengisi rekam medis secara lengkap seperti yang diatur dalam peraturan perundangundangan. Dari semua aspek pelaksanaan tanggung jawab dokter jaga IGD yang positif, namun ada dokter jaga IGD pengganti yang tidak mempunyai
SIP karena kekurangan dokter jaga IGD terutama saat hari libur Lebaran. Dokter jaga pengganti yang berpraktik tanpa memiliki SIP tidak mendapatkan perlindungan hukum, sejak semula telah melanggar hukum administrasi dan dapat dikenai sanksi disiplin dari Dinas Kesehatan Kota/Kabupaten selain sanksi pidana seperti diatur dalam Pasal 76 UU No. 29 tahun 2004 tentang Praktik Kedokteran.

\section{H. Saran}

Saran-saran yang dapat
diberikan terkait dengan
penelitian ini yaitu:

1. Pemerintah seharusnya dapat memberikan perlindungan hukum yang lebih baik bagi dokter sehingga dapat memberikan rasa aman dalam menjalankan praktik kedokteran khususnya penanganan gawat darurat di IGD rumah sakit. Dokter jaga IGD perlu mendapatkan sosialisasikan tentang perlindungan hukum berdasarkan peraturan perundang-undangan.

2. Managemen Rumah Sakit seharusnya mempersiapkan dokter jaga IGD pengganti yang memiliki SIP di Rumah Sakit tersebut terutama pada saat hari libur Lebaran, sehingga masalah penggatian dokter jaga IGD oleh dokter yang tidak 
memiliki SIP, karena kekurangan dokter jaga IGD tetap tidak terulang kembali.

\section{DAFTAR PUSTAKA}

Chazawi. Adami, 2007, Malpraktik Kedokteran Tinjauan Norma dan Doktrin Hukum, Malang: Banyumedia Publising

Hanafiah. M. Yusuf dan Amri Amir, 2016, Etika Kedokteran \& Hukum Kesehatan, Jakarta: Penerbit Buku Kedokteran EGC

Hariadi.Agus.dkk, 2001, Penelitian tentang Aspek Hukum Pelayanan Kesehatan di Lapangan, Jakarta: Badan Pembina Hukum Nasional Depatermen Kehakiman dan HAM RI

Ilyas. Amir, 2014, Pertanggungjawaban Pidana Dokter dalam Malpraktek Medik di Rumah Sakit, Yogyakarta: Rangkang education dan Republik Intitute

Isfandyarie.Anny, 2005, Malpraktek \& Resiko Medik dalam Kajian Hukum Pidana, Jakarta: Prestasi Pustaka

Machmud. Syahrul, 2008, Penegakan Hukum Dan Perlindungan Hukum Bagi Dokter Yang Diduga Melakukan Medikal Malpraktek, Bandung: Mandar Maju

Mertokusumo. Sudikno, 2010, Mengenal Hukum Suatu Pengantar, Yogyakarta: Cahaya Atma Pustaka

Nasution. Bahder Johan, 2005, Hukum Kesehatan Pertanggungjawaban Dokter, Jakarta: Rineka Cipta

Ohoiwutun.Y.A.Triana,2008, Bunga Rampai Hukum Kedokteran, Malang: Bayumedia Publising

Siswati. Sri, 2013, Etika dan Hukum Kesehatan dalam Perspektif Undang-Undang Kesehatan, Jakarta: PT RajaGrafindo Persada

Soekanto. Soerjono, 1989, Aspek Hukum Kesehatan (Suatu
Kumpulan Catatan), Jakarta: Penerbit In-Hill-Co

Soetrisno. S, 2010, Malpraktek Medik \& Mediasi Sebagai Alternatif Penyelesaian Sengketa, Tangerang: Telaga IImu Indonesia

Soewono.H.Hendrojono., 2007, Batas Pertanggungjawaban Hukum Malpraktik Dokter dalam Transaksi Terapeutik, Surabaya: Srikandi

Suryadhimirtha.Rinanto, 2011, Hukum Malpraktik Kedokteran disertai Kasus dan Penyelesaiannya, Perpustakaan Nasional: KDT

Andini. Sarah, 2013, Analisa Kebutuhan Tenaga Keperawatan di Instalasi Hemodialisa Rumah Sakit Umum Pusat Persahabatan Berdasarkan Beban dan Kompetensi Kerja, tersedia di web site http://lib.ui.ac.id/file?file=digital/20 334959-T33029-

Sarah\%20Andini.pdf, diunduh tanggal 1 Mei 2017

Anonim, tersedia di web site http://repository.maranatha.edu/7 966/3/0430050 Chapter1.pdf, diunduh tanggal 22 Februari 2017

Anonim, Dasar Perhitungan Ketenagaan IGD RS, tersedia di web site http://dokumen.tips/embed/dasarperhitungan-ketenagaan-rs.html, diunduh tanggal 1 Desember 2016

Biro Hukum dan Organisasi , 2007 , "Tinjauan Kasus Putusan Mahkamah Kostitusi (MK) dalam Pembentukan Sanksi Pidana pada Undang-Undang Praktik Kedokteran" disampaikan pada kegiatan Temu IImiah "Sistem Pemidanaan di Indonesia" dapat diunduh di https://bphn.go.id, diakses tanggal 25 Mei 2017

Peraturan Walikota Payakumbuh, 2010, tersedia di website https://portal.mahkamahkonstitusi. go.id/eLaw/mg58ufsc89hrsg/1421 5dfe39552facdd2f6130163ebc9a3 ebe90316.pdf, hlm. 3, diunduh tanggal 21 Oktober 2016

Sutrisno. Endang; Elya Kusuma Dewi, Dampak Putusan Mahkamah 


\section{9 | Jurnal Idea Hukum}

Vol. 4 No. 2 Oktober 2018

Magister Hukum Fakultas Hukum Universitas Jenderal Soedirman

Agung Nomor 365 K/PID 2012

Terhadap Kinerja Dokter di

Wilayah III Cirebon, tersedia di website http://journal.umy.ac.id, diunduh tanggal 16 Juli 2017

Tim Penyusun, 2015, Pedoman Penyusunan Panduan Praktik Klinik dan Clinical Pathway dalam Asuhan Terintegrasi Sesuai Standar Akreditasi Rumah Sakit 2012, Jakarta

Wijayanta. Tata, Asas Kepailitan

Hukum, Keadilan dan

Kemanfaatan dalam Kaitan

dengan Putusan Kepailitan

Pengadilan Niaga, tersedia di website

http://www.akademik.fh.unsoed.a

c.id, diunduh tanggal 16 Juli 2017 